\title{
Projekt „Jakość i styl życia oraz plany życiowe i tożsamość mieszkańców pogranicza polsko- -czeskiego po przyjęciu Polski i Czech do Unii Europejskiej”
}

Streszczenie: Artykuł prezentuje projekt realizowany przez uczelnie partnerskie w Polsce (Opole) i Republice Czeskiej (Hawirzów) dotyczący jakości i stylu życia oraz planów życiowych i tożsamości mieszkańców pogranicza polsko-czeskiego po przyjęciu Polski i Czech do Unii Europejskiej. Przedstawiono cele projektu, założenia metodologiczne, wybrane wyniki badań, charakteryzujące cztery kategorie badawcze: jakość i styl życia, plany życiowe i tożsamość mieszkańców pogranicza z perspektywy potencjału społeczno-kulturalnego pogranicza, przyjęcia Polski i Czech do EU, perspektywy pogranicza oraz edukacji międzykulturowej. Badania sondażowe przeprowadzono po stronie polskiej w Euroregionie Pradziad, po stronie czeskiej w Euroregionie Beskidy na łącznej próbie 615 uczniów i 502 studentów. Pozwoliły one na postawienie diagnozy dotyczącej badanych problemów i określenie uwarunkowań badanych kategorii.

Słowa kluczowe: jakość i styl życia, potencjał społeczno-kulturowy, pogranicze, plany życiowe, tożsamości pogranicza

\section{Wstęp}

W opracowaniu będzie mowa o projekcie realizowanym w latach 2019-2020 przez dwie uczelnie partnerskie, funkcjonujące na pograniczu polsko-czeskim - Wyższą Szkołę Administracji i Zarzadzania w Opolu i Uniwersytet PRIGO w Hawirzowie (partner ze strony czeskiej. Opolska uczelnia proponując projekt badawczy pod nazwą: Jakość $i$ styl życia oraz plany życiowe i tożsamość mieszkańców pogranicza polsko-czeskiego po przyjęciu Polski i Czech do Unii Europejskiej nawiązała do tradycji badań nad pograniczami, a zwłaszcza nad tożsamością i zderzeniami kultur na pograniczach, jakie prowadzono w środowisku opolskim w latach 80. i 90. tych ubiegłego wieku. Głównie jed- 
nak odwołano się do projektu Komitetu Badań Naukowych (nr 1 HO 02808 1F) Poczucie tożsamości narodowej i plany życiowe mieszkańców pograniczy (1996-1999), jaki realizowano w Instytucie Nauk Pedagogicznych Uniwersytetu Opolskiego. W ramach tamtego projektu przeprowadzono badania związane z tematem na wszystkich polskich pograniczach i na pograniczach w krajach sąsiednich. Główny cel, jaki przyświecał badaczom, związany był z uchwyceniem głównych czynników warunkujących tożsamość narodową mieszkańców pograniczy, a także ich plany życiowe. Były to wówczas kwestie istotne ze względu na aspiracje wstąpienia przez kraje Europy Środkowej do UE (Jasiński i Lewowicki, 1997, ss. 9-10). Zagadnienia te są istotne nadal w związku z wyjazdami młodzieży do innych krajów i osiedlaniem się tam.

Aktualnie mamy inną sytuację. Polska i Czechy przystąpiły w 2004 roku do UE, wcześniej powstały Euroregiony, w tym Euroregion Pradziad (1997), w 2007 roku oba kraje przystąpiły do strefy Schengen, w 1991 powstał Trójkąt Wyszehradzki, który w 1994 roku został przekształcony w grupę Wyszehradzką V4. Polska podpisała nowe układy o współpracy z Czechami i Słowacją. Wszystko to przyczyniło się do współpracy regionów przygranicznych. (Jasiński i Nowak, 2020, s. 9).

Projekt był realizowany w ramach naboru mikroprojektów w Euroregionie Pradziad. Zespół badawczy tworzyli: (grupa opolska): Z. Jasiński - kierownik projektu, M. Hanulewicz, K. Łangowska-Marcinkowska, Z.M. Nowak, S. Śliwa, M. Černek - koordynator czeski projektu, Ch. Kliková, B. Navrátil, V. Nalepová; M. Murin (Biuro Euroregionu Pradziad w Prudniku, Dokumentacja projektu nr 11_16_009).

Opracowanie ma charakter sprawozdawczy, stąd ograniczono się w nim do zaprezentowania założeń metodologicznych i wybranych wyników ilustrujących główne kategorie badawcze oraz wnioski z badań.

\section{Założenia metodologiczne realizowanego projektu}

\section{Cel projektu, problemy badawcze}

Autorzy projektu przyjęli, że przyjęcie Polski i Czech do Wspólnoty Europejskiej i przystąpienie obu krajów do strefy Schengen przyczyniło się do poprawy poziomu i jakości życia mieszkańców polsko-czeskiego pogranicza, a także do zmiany stylu życia. Stąd głównym celem badań było sprawdzenie, czy zmiany społeczno-polityczne związane z przystąpieniem Polski i Czech do UE mają odzwierciedlenie w jakości życia, poczuciu tożsamości narodo- 
wej i planach życiowych młodych mieszkańców polsko-czeskiego pogranicza. Celem praktycznym badań było sformułowanie postulatów skierowanych do instytucji i organizacji społeczno-kulturalnych, które mogą się przyczynić do kształtowania takiej polityki regionalnej, aby kontakty z partnerami za granicą sprzyjały zbliżeniu, przyczyniały się do budowy pomostów, unikały konfliktów, wspierały wartości i działania sprzyjające poprawie jakości życia na obszarach przygranicznych w duchu edukacji międzykulturowej.

Główny problem badawczy został sformułowany w postaci pytania: $C z y$ $i$ w jakim stopniu przystapienie Polski i Czech oraz następujace w zwiqzku $z$ tym zmiany spoteczno-polityczne i kulturowe warunkuja jakość i styl życia oraz tożsamość i plany życiowe młodych mieszkańców pogranicza polsko-czeskiego. Do problemu głównego sformułowano szereg problemów szczegółowych (Biuro Euroregionu Pradziad - dokumentacja projektu nr 11_16_009). Zakres podjętych badań został zawężony do czterech podstawowych kategorii zawartych w tytule projektu (jakość, styl życia, plany życiowe, tożsamość), co było uwarunkowane możliwościami organizacyjnymi i finansowymi, lecz także uwarunkowaniami metodologicznymi; gdyż badane obszary różnią się m.in. oceną zdarzeń historycznych, sytuacją polityczną, gospodarczą i społeczno-kulturową. Dlatego nie zakładano, że celem badań będzie dokonanie analizy porównawczej, lecz ich celem będzie diagnoza wspomnianych kategorii badawczych (Jasiński i Nowak, 2020, ss.13-14).

\section{Zastosowane metody, techniki i narzędzia badawcze}

W badaniach zastosowano dwie metody badawcze: metodę analizy dokumentów, przynależącą do badań jakościowych (zastosowano technikę analizy treści dokumentów) oraz metodę sondażu diagnostycznego związaną z badaniami ilościowymi (wykorzystano tu technikę ankiety i technikę wywiadu). Pierwszą metodą posłużono się, aby ustalić zmiany potencjału społeczno-kulturowego zarówno po polskiej, jak i czeskiej stronie pogranicza po wejściu RP i RCz do UE oraz zgromadzenie obiektywnych wskaźników wymiaru jakości życia (poziom życia), społeczności pogranicza. Zaś metodę sondażu diagnostycznego zastosowano w celu uzyskania odpowiedzi m.in. na pytania dotyczące: poziomu życia i jakości życia mieszkańców polsko-czeskiego pogranicza, stylu życia w czasie wolnym, systemu wartości mieszkańców pogranicza, korzyści płynących z możliwości swobodnego przekraczania granicy, planów życiowych młodych mieszkańców, tożsamości narodowej i regionalnej, a także wiedzy mieszkańców pograniczy o swoich sąsiadach, 
ich życiu codziennym i problemach itp., aby poznać, jak te procesy obierają indywidualnie młodzi mieszkańcy Euroregionu Pradziad, traktowane jako wymiar subiektywny.

Metodę sondażu diagnostycznego realizowano za pomocą techniki ankiety. Przygotowano dwa kwestionariusze ankiet: U1 dla uczniów ze szkół średnich i U2 dla studentów. Polskie narzędzia badawcze po przetłumaczeniu i adaptacji do czeskich warunków zostały wykorzystane przez stronę czeską. Badania ankietowe przeprowadzono w pierwszej połowie 2020 roku wśród uczniów i studentów zamieszkałych na polsko-czeskim pograniczu Euroregionu Pradziad i czesko-polskim pograniczu Euroregionu Beskidy. Badania ze względu na pandemię były realizowane w części na platformie cyfrowej WSZIA w Opolu. Po stronie polskiej przeprowadzano także 33 wywiady z dorosłymi mieszkańcami Euroregionu Pradziad, związanymi ze współpracą transgraniczną, w celu poznania ich opinii na temat zmian zachodzących w życiu mieszkańców pogranicza po wstąpieniu Polski do UE, o klimacie i jakości współpracy polsko-czeskiej oraz problemach tej współpracy.

\section{Badana grupa}

W badaniach brały udział dwie grupy respondentów: uczniowie ze szkół średnich i studenci. Badaną grupę młodzieży stanowiło 325 uczniów z liceów i szkół zawodowych, w wieku od 15 do 19 lat, 94,7\% z nich miało 17-18 lat. Wśród badanych $81,2 \%$ było mieszkańcami gminy lub powiatu, który graniczy z Czechami, pozostali zaś byli mieszkańcami Euroregionu Pradziad. W badaniach uczestniczyli również studenci ze studiów stacjonarnych i niestacjonarnych z Opola i Nysy, łącznie 222 osoby. W grupie studentów 56,4\% mieściło się w kohorcie 19-30 lat. 83\% studentów i 94,5\% uczniów było przynajmniej raz w Republice Czeskiej. Natomiast 17\% respondentów z grupy studentów i 5,5\% uczniów wskazało, że nigdy nie byli w Czechach.

Ze względu na brak partnera po czeskiej stronie Euroregionu Pradziad badania terenowe przeprowadzono w czeskiej części Euroregionu Beskidy. W badaniu wzięło udział 290 uczniów ze szkół średnich i 280 studentów ze szkół wyższych (z Hawirzowa i Ostrawy), w tym 454 kobiety i 96 mężczyzn (Jasiński i Nowak, 2020, s. 14). 


\section{Charakterystyka terenu badań z perspektywy potencjału społeczno-ekonomicznego}

Teren badań na pograniczu polsko-czeskim dotyczył euroregionu Pradziad i obejmował głównie powiaty: nyski i prudnicki. Do Euroregionu Pradziad należy 70 gmin po stronie czeskiej i 40 gmin po stronie polskiej, w tym szereg gmin w pasie od Prudnika do Opola, które należą do Euroregionu Pradziad. (www. euroregiony.pl; www.euroregionpradziad.pl). Łącznie oba powiaty zajmują $1796 \mathrm{~km}^{2}$, z czego około $2 / 3$ stanowi większy z nich - powiat nyski. Według danych GUS na koniec grudnia 2019 roku na badanym terenie mieszkało 191185 osób (Hanulewicz, 2020, s. 22).

Euroregion Beskidy, w którym prowadzono badania po stronie czeskiej, pod względem administracji państwowej obejmuje powiat Frýdek-Místek (53 gminy), przygraniczną część powiatu Karviná (4 gminy), powiat Ostrava miasto (4 gminy) i powiat Nový Jičín (2 gminy). Powierzchnia obszaru po stronie czeskiej wynosi w przybliżeniu $1012 \mathrm{~km}^{2}$, a żyje na nim 246 tys. Mieszkańców (Navratil, 2020, ss. 64-65; Kliková, 2020, s. 66).

Euroregion Pradziad cierpi na niski przyrost naturalny. W polskiej części Euroregionu już w 1998 roku było 11 gmin z ujemnym przyrostem naturalnym, średnia urodzeń na 1000 obywateli wynosiła 0,7 a w 2017 roku gmin z ujemnym przyrostem naturalnym przybyło i było 30 gmin, przy średniej: $(-1,5)$. Po stronie czeskiej Euroregionu Pradziad w 1998 roku było 23 gminy z ujemnym przyrostem naturalnym, przy średnim przyroście na 1000 obywateli wynoszącym: 1,0. W 2017 roku przyrost naturalny po stronie czeskiej Euroregionu Pradziad wynosił: $(-2,7)$. Jak wynika z tych danych, spadek przyrostu naturalnego postępuje szybciej po stronie czeskiej (Analiza sytuacji..., 2019. s. 121). Inaczej wyglądała sytuacja w badanych miastach. Miasto i gmina Nysa miała w 1998 roku przyrost naturalny wynoszący 1,3 na 1000 obywateli, a miasto i gmina Prudnik, w tym samym roku, miała już ujemny przyrost naturalny, wynoszący $(-0,9)$ na 1000 obywateli, natomiast w 2017 roku ujemny przyrost naturalny pogłębił się i w gminie i mieście Nysa wynosił: $(-2,5)$ na 1000 obywateli, a w mieście i gminie Prudnik: $(-4,8)$ na 1000 obywateli i był 2,6 razy większy niż w województwie opolskim $(-1,8)$ (Analiza sytuacji... 2019, s. 58).

Zarówno województwo opolskie, jak i kraj morawsko-śląski charakteryzuje odpływ obywateli z tego obszaru. Saldo migracji na 1000 obywateli dla województwa opolskiego wynosiło w 2017 roku (-1,2), a dla kraju morawskośląskiego (-2,1). Inaczej przedstawiała się sytuacja w Euroregionie Pradziad, 
w którym w 1998 roku saldo migracji na 1000 obywateli po polskiej stronie euroregionu wynosiło: $(-3,3)$, a po stronie czeskiej $(-2,3)$, natomiast w 2017 roku saldo migracji po stronie polskiej jest korzystniejsze i wynosiło $(-1,1)$, a po stronie czeskiej Euroregionu Pradziad pogłębiło się i wynosiło: $(-4,6)$. W konsekwencji ujemnego przyrostu naturalnego w obu przygranicznych powiatach oraz ujemnego salda migracji powiaty nyski i prudnicki straciły w latach 1995-2019 ponad 10,2\% swojej populacji (Hanulewicz, 2020, s. 27). Przyczyn odpływów mieszkańców pogranicza należy upatrywać głównie w wysokiej stopie bezrobocia w Euroregionie.

Poziom życia i jego jakość zależą od źródeł dochodu. Ich posiadanie zależy od tego, czy ma się pracę. Pod tym względem analizowane powiaty, po transformacji ustrojowej przed przyjęciem Polski do UE, były w bardzo trudnej sytuacji, zostały zamknięte fabryki zatrudniające dużą liczbę pracowników (np. w Nysie Fabryka Samochodów Dostawczych „Nysa”, Zakłady Urządzeń Przemysłowych, a w Prudniku Zakład Obuwniczy w Prudniku i „Frotex”). Powiat nyski charakteryzował się najwyższą stopą bezrobocia w woj. opolskim. Pod koniec stycznia 2004 roku stopa ta wynosiła 34,4\%. W lipcu 2011 roku stopa bezrobocia wynosiła w powiecie nyskim jeszcze 21\%, a w grudniu 2020 roku - 9,0\% (http://www. pup.nysa.pl/statystyki/raporty_roczne, 2021). Podobnie trudna była sytuacja na rynku pracy w powiecie prudnickim. Bezrobocie w tym powiecie w lipcu 2005 roku wynosiło 18,2\%, w 2011 - 17,1\%, natomiast w grudniu 2020, w powiecie prudnickim stopa bezrobocia wynosiła 9,9\%, przy średniej wojewódzkiej 6,1\% (www.pup.prudnik.pl/statystyki/raporty_roczne, 2021).

Podobnie trudna sytuacja na rynku pracy istniała na pograniczu czesko-polskim, w kraju w kraju morawsko-śląskim. Stopa bezrobocia jest tam długotrwale wyższa od średnich wartości dla całej Republiki Czeskiej i w 2000 roku wynosiła $14,3 \%$, będąc o połowę mniejsza niż w powiecie nyskim czy prudnickim w tym samym roku. W 2017 roku ogólna stopa bezrobocia w kraju morawsko-śląskim wynosiła 4,7\%, czyli o 9,6\% mniej niż w roku wstąpienia Czech do UE (Nalepová, 2020, ss. 98-99). Spadek stopy bezrobocia na polskim, jak i czeskim pograniczu jest rezultatem wysiłku władz lokalnych, jak i wsparcia UE, które było ukierunkowane w pierwszych latach przyjęcia Polski i Czech na tworzenie nowych miejsc pracy. Np. Powiatowy Urząd Pracy w Nysie po wstąpieniu Polski do UE uzyskał do września 2006 roku na łagodzenie bezrobocia 20000000 PLN z Funduszy Europejskich („Nyski Rynek Pracy", 2006, 1, s. 6).

Ważne jest też, jakie dochody przynosi praca. Przeciętne średnie miesięczne wynagrodzenie brutto w woj. opolskim wynosiło 2006 roku - 528 euro, 
a w kraju morawsko-śląskim średnia płaca wynosiła 566 euro, natomiast w roku 2016 w woj. opolskim średnia płaca wynosiła 850 euro, a w kraju morawsko-śląskim 903 euro. Kwoty te były jednak niższe od średnich krajowych zarówno w Polsce, jak i Republice Czeskiej (Analiza sytuacji..., 2019, s. 143). Różnice te są jeszcze bardziej dostrzegalne na przykładzie płac w powiatach nyskim i prudnickim. W 2003 roku średnia jeszcze wyraźniej płaca brutto w powiecie nyskim wynosiła 1783,79 PLN, co stanowiło 77,1\% średniej krajowej, natomiast średnia płaca w powiecie prudnickim wynosiła 1744,88 PLN (75,\% średniej krajowej). Natomiast w 2018 roku średnia miesięczna płaca w pow. nyskim wynosiła 3875,88 PLN (80,2\% średniej krajowej), a w powiecie prudnickim 3847,86 PLN (79,6\% średniej krajowej) (Hanulewicz, 2020, s. 31). Średnie miesięczne wynagrodzenie mieszkańców pogranicza polsko-czeskiego było niższe od średniej wojewódzkiej i średniej krajowej.

W tym miejscu warto wspomnieć o średnim dochodzie produktu krajowego brutto. Wynosił on w 2016 roku na 1 mieszkańca w woj. opolskim 1174 Euro, a w kraju morawsko-ostrawskim w tym samym roku 1599 Euro (Analiza sytuacji... 2019, s. 129). Należy jednak przyznać, że dynamika wzrostu płac, dochodu przypadającego na jednego obywatela, spadek stopy bezrobocia były w okresie 2005-2018 wyższe w województwie opolskim niż w kraju morawsko-śląskim. Wiele wskaźników ekonomicznych jest traktowanych jako wskaźniki jakości życia (poziomu życia), takie jak np.: długość dróg ekspresowych i autostrad, liczba oddanych mieszkań w przeliczeniu na 10 tys. mieszkańców, powierzchni mieszkania na 1 osobę, sieć połączeń komunikacyjnych itd. (Nalepová, 2020, ss. 82-83)

Warto również wymienić wskaźniki, które należą obecnie do standardów życia społecznego, np. możliwość korzystania z sieci wodociągowej. W województwie opolskim w 2017 roku korzystało z niej 96,9\% ogółu ludności, a w kraju morawsko-śląskim 99,9\%. Mniej korzystny jest wskaźnik możliwości korzystania z kanalizacji, po stronie polskiej korzystało z niej 72,9\% mieszkańców, natomiast w kraju morawsko-śląskim - 83,3\%. Strona czeska góruje nad nami liczbą oczyszczalni ścieków; w kraju morawsko-śląskim jest ich 161, gdy tymczasem w woj. opolskim mamy ich 75 . W kraju morawskośląskim przeznacza się też większe nakłady na środki trwałe służące ochronie środowiska. Kraj morawsko-śląski należał w poprzednim okresie do najbardziej uprzemysłowionych regionów Republiki Czeskiej, co przyczyniło się do degradacji środowiska naturalnego, stąd dostrzega się konieczność potrzeby przeznaczania obecnie większych nakładów na ochronę środowiska (Analiza sytuacji... 2019, ss. 151-152). 


\section{Młodzież o jakości i stylu życia na polsko-czeskim pograniczu}

Analiza podstawowych obiektywnych wskaźników jakości życia (średnie płace, dochód narodowy przypadający na 1 obywatela, stopa bezrobocia) wykazuje, że są one korzystniejsze po stronie czeskiej. Strona czeska ma lepiej rozwiniętą komunikację kolejową i autobusową, lepiej zorganizowaną i bardziej dostępną służbą zdrowia. Swoje usługi oferuje także po stronie polskiej. Nie sposób tu wymieniać wszystkich wskaźników potencjału społeczno-kulturowego całego polsko-czeskiego pogranicza ze względu na bardzo dużą liczbę danych. Zwłaszcza że po stronie polskiej nie mamy takiego wydawnictwa, jak w Republice Czeskiej „Obce v datech” (2020) [„Gminy w danych”], które w ramach projektu śledzi jakość życia w Pradze i 205 gminach, które posiadają rozszerzone kompetencje, według przyjętych wskaźników w trzech kluczowych dziedzinach: zdrowie i środowisko, bezpieczeństwo materialne i edukacja oraz relacje i usługi. Zagregowane wskaźniki, skorygowane statystycznie, wyznaczają w indeksie pozycję mówiącą o jakości życia w gminie (0 najniższy poziom, 10 najwyższy poziom jakości życia). Są to jednak wskaźniki, które zdaniem Nalepovej (2020) koncentrują się na obiektywnych wyznacznikach jakości życia. Niestety, jest cały szereg gmin z kraju morawskośląskiego, które zajmują pozycję w drugiej setce tego indeksu, w tym jedna z gmin (Orłowa) zajmuje w niej ostatnią, 206. pozycję jako "gmina najgorsza do życia" (Nalepová, 2020, s. 88), co wcale nie musi oznaczać, że tak myślą i odczuwają mieszkańcy Orłowej (w miejscowości tej w 1909 roku staraniem Towarzystwa Szkoły Ludowej w Krakowie i Macierzy Szkolnej Księstwa Cieszyńskiego utworzono Polskie Gimnazjum Realne im. Juliusza Słowackiego). Może się wydawać, że dla wskaźników tych zostały przyjęte zbyt wysokie wartości, ale przecież chodzi o jakość życia, a nie tylko o egzystencję.

Przyjęto założenie, że istnieje związek między potencjałem społeczno-kulturowym a jakością życia i planami życiowymi oraz tożsamością mieszkańców pogranicza.

Nowym elementem krajobrazu badanego pogranicza są ścieżki rowerowe. W 2019 roku ich długość wynosiła $92,6 \mathrm{~km}$. Czynią one codzienne życie mieszkańców bezpieczniejsze oraz stwarzają warunki do rekreacji, jest to ważny element jakości życia, świadczący też o jego poziomie. Musiała się zmienić mentalność społeczeństwa, żeby uznało ono, że ścieżki rowerowe są potrzebne, ale też musiały powstać możliwości finansowe, aby można było 
sobie na nie pozwolić. Dla jakości życia jest ważna opieka zdrowotna. W powiecie nyskim i prudnickim w latach 1995-2019 liczba punktów medycznych w opiece ambulatoryjnej powiększyła się czterokrotnie - do 92 w 2019 roku. Wzrosła także liczba aptek i punktów aptecznych do 68 w 2019 roku. Liczba łóżek w szpitalach ogólnych, z 1059 w 2005 roku do 1273 w roku 2018 (wzrost o 17\%). Mimo tych coraz korzystniejszych wskaźników ogólna ocena służby zdrowia w opiniach badanych polskich respondentów spotkała się z krytyką. Przyczyną tego jest niska dostępność do usług medycznych wynikająca z braku pracowników służby zdrowia.

Ważnym elementem potencjału społeczno-kulturowego jest poziom zaspokojenia potrzeb edukacyjnych. W stosunku do 1995 roku zmalała liczba techników i szkół zawodowych, stąd młodzież wspomina o braku możliwości zdobycia atrakcyjnego zawodu. Potrzeby edukacyjne są zaspokojone pod względem ilościowym, natomiast nie jakościowym.

Oba badane powiaty dysponują bogatą siecią placówek kulturalno-oświatowych, które w pełni zaspakajają potrzeby mieszkańców, ze względu na zmianę modelu uczestnictwa w kulturze i formach spędzania czasu wolnego. W 2020 roku istniały 64 biblioteki publiczne oraz 3 punkty biblioteczne. Na terenie omawianych powiatów funkcjonowały 3 kina (w 1995 roku było ich 5), 4 muzea. Mimo wzrostu wystaw stałych i czasowych, organizowanych rokrocznie odczytów, seminariów, koncertów, lekcji bibliotecznych liczba odwiedzających muzea spadła o 53\% w stosunku do 1999 roku. Na popularności zyskują za to imprezy masowe, których liczba, podobnie jak liczba uczestników, wzrasta. W 2019 roku zorganizowano 25 imprez masowych, z łączną liczbą uczestników 87 000. Na uwagę zasługuje funkcjonowanie sieci ośrodków kultury, nie tylko w miastach, ale także w środowisku wiejskim (działalność większości $\mathrm{z}$ nich została zawieszona w okresie pandemii). Do najbardziej popularnych form działalności należą takie zajęcia, jak: zajęcia taneczne, muzyczne, informatyczne, plastyczne, a także zajęcia teatralne i szachowe.

W Euroregionie Pradziad, po stronie polskiej, jak i po stronie czeskiej, jest wiele miejsc atrakcyjnych dla turystów. Rozwój turystyki jest związany z posiadaniem bazy noclegowej. Badane powiaty dysponowały w 2019 roku 3844 miejscami noclegowymi.

Ośrodki gminne i stowarzyszenia lokalne sięgały umiejętnie po środki unijne, co pozwalało na wzbogacanie i uatrakcyjnienie działalności kulturalno-oświatowej w regionie. Na terenie powiatu nyskiego i prudnickiego latach 2007-2013 zrealizowano ponad 170 projektów w ramach programu współpracy polsko-czeskiej o wartości powyżej 40 mln euro. Natomiast w ra- 
mach tzw. Funduszu Mikroprojektów zrealizowano wiele inicjatyw na rzecz społeczności lokalnych. W latach 2014-2020 oba powiaty łącznie uzyskały z EFRR 5,7 mln euro dotacji (Hanulewicz, 2020, ss. 45-46).

Analiza potencjału społeczno-kulturowego obszarów przygranicznych, po obu stronach granicy, po powstaniu euroregionów pozwala na stwierdzenie, że to powstanie i działalność Euroregionów na tym pograniczu przyczyniły się do poprawy infrastruktury tych obszarów, a tym samym warunków życia i jego jakości. Wnikliwa analiza wielu wskaźników rozwoju kraju morawsko-śląskiego przeprowadzona przez E. Nalepovą wykazuje, że „aczkolwiek wiele wskaźników rośnie (wskaźniki efektywności gospodarczej, wskaźniki związane z poprawą stanu środowiska, wskaźniki odzwierciedlające poziom zatrudnienia, wskaźniki odzwierciedlające przedsiębiorczość oraz wskaźniki związane z edukacją.), to jednak w wielu przypadkach są one niższe w stosunku do całej Republiki Czeskiej” (Nalepová, 2020, s. 103). Konstatację tą można odnieść także do badanych powiatów po stronie polskiej.

Czeskie badaczki Ch. Kliková i V. Nalepová koncentrują się na modelach jakości i stylu życia z perspektywy obiektywnej, odwołują się do wskaźników dla całego kraju morawsko-śląskiego, natomiast Z.M. Nowak bardziej zwraca uwagę na jakość życia jako konsekwencje dobrostanu, a nie tylko dobrobytu, który rzutuje na poziom życia, a w zdecydowanie mniejszym stopniu na jakość życia. Koncentruje się na tym, jak fakt przyjęcia Polski do UE zmienił życie w odczuciu subiektywnym badanej młodzieży (Nowak, 2020, s. 112). Uzyskane odpowiedzi pozwalają odczytać zmiany w jakości i poziomie życia, np. uzyskać odpowiedź na pytanie, jaki jest cel wyjazdu Polaków do Czech. Na pierwszym miejscu zarówno studenci $(64,7 \%)$, jak i uczniowie $(86,2 \%)$ przyznali, że głównym celem jest wypoczynek weekendowy, dopiero na drugim miejscu studenci $(50,6 \%)$ i uczniowie $(83,1 \%)$ uznali, że celem tym jest zwiedzanie kraju sąsiadów. Na miejscu trzecim studenci umieścili wypoczynek wakacyjny (34,4\%), a uczniowie zakup dóbr konsumpcyjnych. Dostrzegalny jest wybór na pierwszych miejscach w obu grupach celów związanych $\mathrm{z}$ realizacją potrzeb na wyższym poziomie (w koncepcji Maslowa), gdy przed 2004 roku tym głównym celem był zakup dóbr materialnych (Jasiński, 2004, s. 71) obecnie są to potrzeby wyższego rzędu (wypoczynek weekendowy i wakacyjny, poznawanie kraju sąsiadów). Ta zmiana celów była możliwa dzięki poprawie warunków materialnych, czego wyrazem jest wzrost miesięcznych płac mieszkańców pogranicza. Poprawa warunków życia pozwala na realizację potrzeb wyższego rzędu. Na pytanie: Jak oceniasz poziom życia po obu stronach granicy? - odpowiedź łączna uczniów i studentów brzmiała, 
że na pograniczu polsko-czeskim lepiej żyje się Czechom (43,8\%), a 58,8\% odpowiedziało, że poziom życia po obu stronach pogranicza jest taki sam. Mamy tu przykład, że subiektywny poziom oceny może się różnić od obiektywnych wskaźników. Tak jest w tym przypadku. Obiektywne wskaźniki warunków życia po stronie czeskiej, takie jak: średnia miesięczna płaca, średni dochód na jednego mieszkańca, są wyższe niż po polskiej stronie pogranicza, a stopa bezrobocia jest wyższa w Polsce. Można dodać jeszcze inne wskaźniki, korzystniejsze dla strony czeskiej (usługi turystyczne, usługi zdrowotne, komunikacja, które składają się obiektywnie na wyższy poziom życia po stronie czeskiej. Natomiast badani uznali w większości, że poziom życia po polskiej i czeskiej stronie jest taki sam. Może zastanawiać, skąd wynika inna ocena. Wydaje się, że jest to konsekwencja rzadkich wyjazdów do Czech, co nie pozwala na obiektywną ocenę. Stąd nie należy się dziwić, że 73,1\% ogółu badanych miało trudności w ocenie, jak się żyje Czechom.

Ocena jakości życia zależy od uznawanych wartości. Jako najważniejsze, zarówno studenci, jak i uczniowie uznali szczęście rodzinne (ranga I), zdrowie (ranga II), uczciwe życie (ranga III). Natomiast najniższą rangę, zarówno wśród studentów, jak i uczniów w systemie wartości, zajęły sława i sukces. Jest zastanawiające, że najwyższy wskaźnik - jako wartości nieistotnej - został przyznany przez uczniów i studentów wierze i religii - uczniowie $(23,7 \%)$, natomiast studenci określili ich wartość na 4,6\%. Wartości te Z. Nowak rozpatruje ze względu na obszar pogranicza, które wymaga przestrzegania norm mieszkańców tego obszaru, aby życie było spokojne i w miarę bezkonfliktowe, sprzyjało budowaniu mostów, a nie podziałów. Uważa, że „szczególnie ważne są wartości, które służą umiejętności w nawiązywaniu i podtrzymywaniu więzi z ludźmi..." (Nowak, 2020, s. 120). Dokonuje analizy postaw komunikacyjnych mieszkańców pogranicza polsko-czeskiego. Badani oceniają mieszkańców pogranicza jako otwartych na problemy Polski, tolerancyjnych, życzliwych. Autorka dostrzega jednak, że ponad 51\% badanych studentów i $63,4 \%$ badanych uczniów nie potrafiło określić, jakie są postawy komunikacyjne mieszkańców tego obszaru, a także, że znaczny procent badanych ma nikłą wiedzę o swoim regionie i partnerach z Czech, co może utrudniać budowanie pozytywnych relacji we współpracy transgranicznej. W prowadzonych badaniach interesował nas styl życia ze względu na sposoby spędzania czasu wolnego. Zarówno studenci, jak i uczniowie najczęściej wybierali jako formę spędzania czasu wolnego rozwijanie swoich zainteresowań. Obie grupy respondentów preferują aktywne formy spędzania czasu wolnego. Warto odnotować, że prawie $10 \%$ uczniów i studentów stwierdziło, że „nie ma czasu wolnego”. 


\section{Plany życiowe i tożsamość}

W badaniach nie chodziło o poznanie planów życiowych młodzieży w szerokim znaczeniu jako sumy różnych planów jednostki, wynikających z aspiracji jednostki, osobowości, uwarunkowań zewnętrznych, orientacji życiowych, etapów rozwoju, wzorów życiowych itp. (Lewowicki, 2004, s. 9), ale poznanie, jakie plany życiowe mają młodzi mieszkańcy pogranicza, czy zamierzają swoje dalsze losy życiowe związać z pograniczem, jak zechcą mu służyć i czym ma być dla nich ta ziemia. Jeśli jednostki operatywne, wykształcone, pozostaną w swoim miejscu zamieszkania, to region będzie miał większe szanse rozwoju. Ta kwestia dla badanego pogranicza polsko-czeskiego, jak i czesko-polskiego jest ważna, gdyż wiąże się z pozostaniem lub odpływem obywateli z regionu, na co cierpi to pogranicze. Wiedza ta ma wymiar praktyczny i może przyczynić się do budowania przez władze lokalne strategii przeciwdziałającej migracjom wewnętrznym i zewnętrznym poprzez podniesienie jakości i poziomu życia.

Uczniom i studentom zadano szereg pytań, które pozostają w związku z planami życiowymi. Dotyczyły one związku emocjonalnrgo ze swoją miejscowością i regionem, atutów miejscowości, w której mieszkają, i regionu, planów dotyczących miejsca swojego przyszłego zamieszkania, deklaracji pozostania w Polsce. Na pytanie dotyczące związku emocjonalnego ze swoją miejscowością 65,9\% uczniów i 75,3\% studentów zadeklarowało, że są emocjonalnie z nią związani, natomiast związki emocjonalne $\mathrm{z}$ regionem zadeklarowało $61 \%$ uczniów i 72,3\% uczniów, w tym 92,5\% uczniów i 98,2\% studentów uzasadniło swój związek z miejscowością lub regionem. Uzasadnienia te wiązały się z oczywistymi faktami, takimi jak: miejsce urodzenia i wychowania w tej miejscowości, zamieszkiwania tam rodziców, rodzeństwa; faktów związanych z ważnymi wydarzeniami, uczęszczanie do przedszkola, ukończenie szkoły, działalność w klubie, zespole, ale także sentymentalne wspomnienia zabaw, pierwszych sympatii. Najwyższy procent wskazań (średnia 25,4\%) dotyczył uzasadnienia związku emocjonalnego ze swoją miejscowością ze względu na to, że było to miejsce wychowania, czegoś, co kojarzy się z „krajem lat dziecinnych" i było związane z poczuciem rodzinnego bezpieczeństwa, spokoju i miłości. Okazuje się, że silniej związani są ze swoją miejscowością i regionem byli studenci. Różnice te wynikają zapewne z większego doświadczenia życiowego, w tym możliwości porównania swojej miejscowości do innych. 
M. Murin w badaniach na czesko-polskim pograniczu uchwycił zależność między związkiem emocjonalnym a deklaracją pozostania w swoim regionie. Ustalił, że gdy spada emocjonalne przywiązanie do regionu, to rośnie procent tych, którzy raczej nie planują lub zdecydowanie nie planują mieszkać w przyszłości w Czechach (Murin, 2020, s. 185). Związek ten potwierdził się także w odniesieniu do polskiego pogranicza. Deklaracja pozostania w swojej miejscowości wynika z atutów, jakie posiadały miejscowości, a jakie dostrzegli badani. Tu ujawnia się pełna zbieżność w poglądach badanych uczniów i studentów, którzy za trzy najważniejsze atuty swoich miejscowości uznali: 1. spokój - 80,6\%, 2. bezpieczeństwo - 75,5\%, 3. dobre relacje sąsiedzkie - 63,6\% (Jasiński, 2020, s. 222). Stąd nieprzypadkowo V. Nalepová (2020, s. 101) określiła zgodnie wybrane przez uczniów i studentów atuty (spokój, bezpieczeństwo, dobre relacje sąsiedzkie) jako „ciche otoczenie“, wskazując równocześnie, że trudno jest zobiektywizować to określenie. Niewątpliwie cenimy sobie w otoczeniu spokój, poczucie bezpieczeństwa, dobre relacje sąsiedzkie, ale o pozostaniu decydują raczej takie kwestie, jak: dostępność do pracy, dobra służba zdrowia, możliwości kształcenia, komunikacja. Kolejne pozycje różnicowały uczniów i studentów. Inna sytuacja życiowa, której doświadczają studenci, zwłaszcza ci pracujący, sprawia, że ich wybory były bardziej związane z problemami dnia codziennego.

Tabela 1. Deklaracje pozostania w przyszłości we własnym kraju przez uczniów i studentów polskich oraz czeskich w \% [2020]

\begin{tabular}{|l|c|c|c|c|}
\hline \multirow{2}{*}{$\begin{array}{c}\text { Zamierzam w przyszłości pozo- } \\
\text { stać w Polsce / w Czechach... }\end{array}$} & $\begin{array}{c}\text { Uczniowie } \\
\text { polscy }\end{array}$ & $\begin{array}{c}\text { Uczniowie } \\
\text { czescy }\end{array}$ & $\begin{array}{c}\text { Studenci } \\
\text { polscy }\end{array}$ & $\begin{array}{c}\text { Studenci } \\
\text { czescy }\end{array}$ \\
\cline { 2 - 5 } & $\%$ & $\%$ & $\%$ & $\%$ \\
\hline zdecydowanie tak & 19,1 & 28,0 & 55,5 & 49,2 \\
\hline raczej tak & 29,2 & 50,0 & 29,4 & 42,9 \\
\hline trudno powiedzieć & 35,1 & 2,0 & 11,0 & 0,7 \\
\hline raczej nie & 11,1 & 7,0 & 2,7 & 6,1 \\
\hline zdecydowanie nie & 5,5 & 3,0 & 1,4 & 1,1 \\
\hline Ogółem & 100,0 & 100,0 & 100,0 & 100,0 \\
\hline
\end{tabular}

Źródło: opracowanie własne na podstawie danych wyników badań polskich i badań czeskich w ramach projektu.

W tym kontekście zapytano uczniów i studentów, czy zamierzają w przyszłości pozostać we własnym kraju? Odpowiedzi na to pytanie, jakich udzielili uczniowie i studenci polscy oraz uczniowie i studenci z czeskiej strony pogranicza, zawiera tabela 1. Jeśli dodamy odpowiedzi: zdecydowanie tak i raczej tak, to łącznie 48,3\% uczniów polskich i 84,9\% studentów polskich 
deklaruje pozostanie w przyszłości w Polsce, a 78\% uczniów czeskich i 91,4\% czeskich studentów deklaruje pozostanie w Czechach. Ta różnica między odsetkiem uczniów i studentów w Polsce, która w przyszłości nie zamierza pozostać w kraju, wynika z krytycznej oceny poziomu życia w regionie. Znajduje to także potwierdzenie w niektórych wskaźnikach obiektywnych, które były wcześniej analizowane (Murin, 2020, ss. 182-186; Śliwa, 2020, s. 156).

Badania prowadzone na Uniwersytecie Opolskim, w ramach wspomnianego projektu Tożsamość i plany życiowe mieszkańców pogranicza, wśród uczniów wykazały, że 32,9\% uczniów z polsko-czeskiego pogranicza wiązało swoje przyszłe plany życiowe $\mathrm{z}$ innym krajem. Pozostanie $\mathrm{w}$ kraju deklarowało 67,6\% (Jasiński, 2004, s. 71). Podobna była sytuacja na pograniczu czesko-polskim. Chęć wyjazdu za granicę i wiązanie swoich losów w przyszłości z innym krajem dotyczyła wówczas $32,5 \%$ czeskiej młodzieży z tego pogranicza (Krejči i Langr, 2004, s. 53). Jak można wytłumaczyć fakt, że procent polskich uczniów i studentów, którzy chcą pozostać w przyszłości w Polsce, jest obecnie mniejszy $(48,3 \%)$ niż w 1997 roku $(67,6 \%)$ na tym samym pograniczu? Jest to sygnał groźny dla Euroregionu i woj. opolskiego. Złożyło się na to kilka czynników: przyjęcie Polski do UE, a w następstwie otwarcie rynków pracy dla pracowników z nowych krajów UE, nauka języków zachodnich w szkołach po 1990 roku obniżyły barierę językową, wzrost aspiracji do poprawy sytuacji życiowej, trwające wysokie wskaźniki bezrobocia w badanych powiatach, brak stabilnego zatrudnienia, zainteresowanie części krajów zachodnich „polskimi robotnikami”, którzy okazali się niezłymi i w dodatku stosunkowo tanimi fachowcami. Młodzi wobec braku pracy w kraju decydowali się na wyjazdy za granicę i podejmowanie pracy poniżej swoich kwalifikacji. Zakładając często, że pozostanie za granicą nie musi trwać ciągle.

Pewnym zaskoczeniem dla badaczy był fakt bardzo niskiego wpływu otwartości granicy państwowej na plany życiowe zarówno uczniów, jak i studentów. Najwyższy wpływ uczniowie ocenili na sposób spędzania czasu wolnego (połączona kategoria odpowiedzi (zdecydowanie tak i raczej tak $(38,1 \%)$, przy równocześnie „trudno powiedzieć” - 24,3\% i odpowiedzi „raczej nie” i „zdecydowanie nie” 37,6\%. Odpowiedzi studentów jeszcze bardziej potwierdzały nikły wpływ otwartości granicy na decyzje życiowe. Studenci uznali, podobnie jak uczniowie, że największy wpływ dotyczy sposobów spędzania czasu wolnego (20,3\%). Niski wpływ otwarcia granic na plany życiowe można uzasadnić tym, że plany życiowe stanowią wypadkową wielu czynników, w tym sprzyjających i hamujących. Otwarcie granic nie należy - zdaniem badanych - do szczególnie ważnych na tym pograniczu. Zarówno 
uczniowie, jak i studenci uznali, że otwarcie granic miało najmniejszy wpływ na zmianę miejsca zamieszkania.

Plany życiowe pozostają w związku z tożsamością regionalną i etniczną. Stąd kolejna część jest poświęcona tożsamości. W badanej grupie wystąpiły różne rodzaje tożsamości: tożsamości narodowe (polska, czeska, niemiecka, rosyjska), tożsamość regionalna (śląska zarówno po stronie polskiej, jak i czeskiej oraz morawska, wałaska, „czechosłowacka” po stronie czeskiej), tożsamości ponadnarodowe (europejska i obywatel świata). Mamy tu do czynienia z tożsamościami rozproszonymi. Sam fakt wystąpienia innych tożsamości oprócz narodowych świadczy o otwartości uczniów, jak i studentów „na obcych".

Tabela 2. Poczucie tożsamości uczniów ze szkół średnich i studentów na pograniczu polsko-czeskim w 2020 roku, w Euroregionie Pradziad oraz czesko-polskim w Euroregionie Beskidy

\begin{tabular}{|c|c|c|c|c|c|c|c|c|}
\hline \multirow{2}{*}{$\begin{array}{l}\text { Czuję } \\
\text { się głównie: }\end{array}$} & \multicolumn{2}{|c|}{$\begin{array}{c}\text { Uczniowie } \\
\text { polscy }\end{array}$} & \multicolumn{2}{|c|}{$\begin{array}{c}\text { Uczniowie } \\
\text { czescy }\end{array}$} & \multicolumn{2}{|c|}{$\begin{array}{l}\text { Studenci } \\
\text { polscy }\end{array}$} & \multicolumn{2}{|c|}{$\begin{array}{c}\text { Studenci } \\
\text { czescy }\end{array}$} \\
\hline & $\mathrm{L}$ & $\%$ & $\mathrm{~L}$ & $\%$ & $\mathrm{~L}$ & $\%$ & $\mathrm{~L}$ & $\%$ \\
\hline Polakiem/ Czechem & 248 & 76,3 & 212 & 73,1 & 165 & 75,8 & 242 & 86,4 \\
\hline Czechem/Polakiem & 1 & 0,3 & 2 & 0,7 & 0 & 0 & 3 & 1,1 \\
\hline Niemcem & 1 & 0,3 & 2 & 0,7 & 0 & 0 & 1 & 0,4 \\
\hline Rosjaninem & 1 & 0,3 & 0 & 0 & 0 & 0 & 0 & 0 \\
\hline Ślązakiem & 20 & 6,2 & 9 & 3,1 & 24 & 11,0 & 12 & 4,3 \\
\hline Europejczykiem & 20 & 6,2 & 18 & 6,2 & 14 & 6,4 & 11 & 3,8 \\
\hline Obywatelem świata & 29 & 8,9 & 15 & 5,2 & 11 & 5,0 & 1 & 0,4 \\
\hline Nie należę do żadnej z tych grup & 5 & 1,5 & 7 & 2,3 & 4 & 1,8 & 1 & 0,4 \\
\hline Brak danych & 0 & 0 & 25 & 8,7 & 0 & 0 & 9 & 3,2 \\
\hline Ogółem & 325 & 100 & 290 & 100 & 218 & 100 & 280 & 100 \\
\hline
\end{tabular}

Źródło: zestawienie własne z Ankiety U-1 pyt. 11; ankieta S-1, pyt. 11 (badania polskie i badania czeskie).

Można przyjąć, że jest to konsekwencja przynależności Polski i Czech do EU, możliwości odwiedzania przez uczniów i studentów krajów członkowskich, poznawania kultury, warunków życia itd. W rezultacie nastąpił niewielki wzrost deklaracji mówiących o „czuciu” się Europejczykiem w stosunku do badań przeprowadzonych w 1997 roku (wówczas deklarowało 4,04\% uczniów szkół średnich, a w roku 2007 - 5,2\%). Natomiast poczucie, że jest się „obywatelem świata”, wzrosło u uczniów z 5,5\% w 1997 roku do 8,9\% w 2020 roku (tab. 2). Potwierdza to, że na pograniczach umacnia się tendencja do tożsamości wielorakiej (Jasiński, 2020, ss. 219-220; Černek i Heinz, 2020, ss. 202-203). 
Po polskiej stronie pogranicza nie ma istotnych różnic statystycznych w deklaracji bycia Polakiem między uczniami ze szkół średnich i studentami - różnica ta wynosi zaledwie $0,5 \%$ na korzyść uczniów. Niewielkie też są różnice między odsetkiem deklaracji narodowej uczniów polskich i czeskich (na korzyść uczniów ze szkół polskich o 3,2\%). Natomiast dostrzegalna jest znaczna różnica między studentami czeskimi i polskimi w zakresie deklaracji tożsamości narodowej. Różnica ta wynosi 10,6\% na korzyść studentów czeskich. Większym zainteresowaniem cieszą się „nowe tożsamości” wśród uczniów niż studentów. Może to świadczyć o wzroście aspiracji młodzieży, możliwości wyjazdów na studia, za pracą czy w celach turystycznych, być może także mody. Tu wyższe wskaźniki odnotowujemy wśród młodzieży polskiej. Zarówno po stronie polskiej, jak i czeskiej wskaźniki związane $\mathrm{z}$ „nowymi tożsamościami” są zróżnicowane. W przypadku śląskiej tożsamości etnicznej wskaźnik ten wśród studentów polskich był większy o 4,8\% od polskich uczniów, o 1,2\% wyższy wśród studentów czeskich od uczniów ze szkół czeskich. Podobnie wyższy był o 0,2\% wśród studentów polskich wskaźnik dotyczący czucia się głównie „Europejczykiem” od uczniów. Natomiast czucie się głównie „obywatelem świata” wśród polskich studentów jest niższe od uczniów ze szkół średnich o 3,6\%. Podobnie niski wskaźnik dotyczący bycia obywatelem świata wśród studentów czeskich wynosił 0,4\%, gdy wśród uczniów wynosił on $5,2 \%$.

W deklaracji polskiej tożsamości narodowej nie ma istotnych różnic statystycznych ze względu na płeć. Po obu stronach granicy potwierdziło się stwierdzenie, że im silniejszy jest związek emocjonalny z regionem, im więcej atutów ma region, tym jest większa szansa, że młodzież nie opuści regionu czy kraju w przyszłości. Optymistyczny jest fakt, że zmniejszył się wskaźnik młodzieży, która chce w przyszłości wyjechać z Polski z 36,6\% w 1997 do $20,7 \%$ w roku 2020, co może świadczyć o poprawie warunków życiowych i możliwościach na pograniczu i znajduje potwierdzenie w wielu wskaźnikach obiektywnych.

W badaniach kwestie tożsamości, planów życiowych ujmowano w kontekście Teorii Zachowań Tożsamościowych na pograniczu, opracowanej przez Tadeusza Lewowickiego. Stąd analizowano system wartości, a także wartości warunkujące m.in. tożsamość kulturową, narodową, a także indywidualną i zbiorową. W przypadku tożsamości indywidualnej najważniejsze okazały się wartości: praca zawodowa, wolność głoszenia poglądów, szacunek u ludzi. Z kolei w przypadku tożsamości zbiorowej badani uznali za najważniejsze: pomyślność ojczyzny, religię, udział w życiu społeczno-politycznym. „Bada- 
na młodzież wykazuje wysoki stopień tolerancji i sympatii wobec Czechów, co stwarza atmosferę do rozwijania współpracy i kontaktów na pograniczu polsko-czeskim w Euroregionie Pradziad" (Jasiński, 2020, s. 232).

\section{Zakończenie}

Badania przeprowadzone w ramach zrealizowanego projektu pozwoliły na poznanie, w jakim zakresie zmieniło się życie mieszkańców pogranicza polsko-czeskiego i czesko-polskiego od 2004 roku, uchwycenie czynników, które warunkowały poprawę warunków życia na pograniczu. Świadczy o tym wiele wskaźników ekonomicznych i społecznych charakteryzujących powiat nyski i powiat prudnicki, które mają wpływ na poziom i jakość życia, ale także na to, kim się czują mieszkańcy, jakie mają plany życiowe i jakie są ich oczekiwania w stosunku do siebie, środowiska i innych, w tym sąsiadów z drugiej strony granicy.

Badana młodzież, a także osoby znaczące w swoich środowiskach na pograniczu dostrzegają pozytywne zmiany, jakie nastąpiły na pograniczu od roku 2004, takie jak: wzrost liczby oddanych mieszkań, pełne zaspokojenie potrzeb w zakresie edukacji przedszkolnej, poprawa bazy materialnej placówek kulturalno-oświatowych, poprawa bazy turystycznej, poprawa jakości dróg, wzrost średniej miesięcznej płacy brutto. Młodzież bardzo wysoko ocenia atrakcje turystyczne regionu, poczucie bezpieczeństwa i spokój, natomiast krytycznie ocenia stan służby zdrowia, możliwości znalezienia atrakcyjnej pracy oraz komunikację drogową i kolejową na pograniczu.

Szczególną wartość w swoich miejscach zamieszkania dostrzegają respondenci w dobrych relacjach sąsiedzkich, poczuciu bezpieczeństwa i spokoju. Badani wykazali się skromną wiedzą o postaciach ważnych dla regionu, o zabytkach w regionie, ważniejszych imprezach regionalnych i formach współpracy transgranicznej. Może to świadczyć o niedostatkach edukacji regionalnej prowadzonej w szkołach. Jej celem powinno być dostarczanie wiedzy o regionie i emocjonalne wiązanie jednostek z regionem, co może przyczynić się do zahamowania wewnętrznej i zewnętrznej migracji na pograniczu. Należy wykorzystać w szerszym zakresie media do popularyzacji regionu, wiedzy o jego problemach i osiągnięciach. Dotyczy to wszystkich podmiotów działających na pograniczu polsko-czeskim, w tym stowarzyszenia Euroregionu Pradziad. Należy pogłębić i poszerzyć informacje o dorobku i perspektywach rozwojowych obu państw w sferze zarówno gospodarki, jak i kultury, oświaty, nauki. Mogłoby się to przyczynić do jeszcze lepszego po- 
znania i rozumienia partnerów zagranicznych i w rezultacie, do zacieśnienia transgranicznych więzi (Łangowska-Marcinkowska, 2020, ss. 146-150).

\section{Bibliografia}

Analiza sytuacji społecznej i gospodarczej obszaru Euroregionu Pradziad. Analyza spolećenske a hospodarske situace na uzemi Euroregionu Praděd.2019. Stowarzyszenie Gmin Polskich Euroregionu Pradziad. Informacje statystyczne. Statisticke informace. ČSŮ. Urząd Statystyczny w Opolu.

Biuro Euroregionu Pradziad, dokumentacja projektu nr 11_16_009.

Černek, M.i Heinz, M. 2020. Problemy tożsamości mieszkańców czesko-polskiego pogranicza w Euroregionie Beskidy. W: Jasiński, Z. i Nowak, Z. red. Jakość i styl życia oraz plany życiowe i tożsamość kulturowa mieszkańców polsko-czeskiego pogranicza po przyjęciu Polski i Czech do Unii Europejskiej. Kraków: Wydawnictwo Petrus, ss.189-209.

Hulewicz, M. 2020. Potencjał społeczno-kulturowy polskiego pogranicza na przykładzie powiatów nyskiego i prudnickiego. W: Jasiński, Z. i Nowak, Z. red. Jakość i styl życia oraz plany życiowe i tożsamość kulturowa mieszkańców polsko-czeskiego pogranicza po przyjęciu Polski i Czech do Unii Europejskiej. Kraków: Wydawnictwo Petrus, ss. 17-48.

Jasiński, Z. i Kozłowska, A. red. 1997. Tożsamość młodzieży na pograniczach.

Opole: Instytut Nauk Pedagogicznych Uniwersytetu Opolskiego.

Jasiński, Z. 2004. Plany życiowe i zamierzenia życiowe młodzieży polskiej z pogranicza polsko-czeskiego. W: Jasiński, Z., Lewowicki, T. i Nikitorowicz, J. red. Plany życiowe młodzieży z terenów pograniczy. Opole: Instytut Nauk Pedagogicznych Uniwersytetu Opolskiego, ss. 55-72.

Jasiński, Z., Lewowicki, T. i Nikitorowicz, J. red. 2004. Plany życiowe mtodzieży z terenów pograniczy. Opole: Instytut Nauk Pedagogicznych Uniwersytetu Opolskiego.

Jasiński, Z. 2020. Identyfikacja narodowa i regionalna mieszkańców pogranicza polsko-czeskiego z perspektywy Euroregionu Pradziad. W: Jasiński, Z. i Nowak, Z. red. Jakość i styl życia oraz plany życiowe i tożsamość kulturowa mieszkańców polsko-czeskiego pogranicza po przyjęciu Polski i Czech do Unii Europejskiej. Kraków: Wydawnictwo Petrus, ss. 211-235.

Jasiński, Z. i Nowak, Z. red. 2020. Jakość i styl życia oraz plany życiowe i tożsamość kulturowa mieszkańców polsko-czeskiego pogranicza po przyjęciu Polski i Czech do Unii Europejskiej. Kraków: Wydawnictwo Petrus. 
Kasperek, B. red. 2014, Euroregiony pogranicza polsko-czeskiego. Cieszyn: Stowarzyszenie Rozwoju i Współpracy Regionalnej „Olza”.

Kosowska-Rataj, J. i Nycz, E. red. 2008. Podmiotowość i tolerancja w społecznościach lokalnych pogranicza polsko-czeskiego. Subjektivita a tolerance v lokálních společenstvích v polsko-českém pohraničí. Opole: Instytut Śląski Sp.z o.o.

Lewowicki, T. red. 1994. Poczucie tożsamości narodowej młodzieży. Studium z pogranicza polsko-czeskiego. Cieszyn: UŚ - Filia w Cieszynie.

Lewowicki, T. 2004. O pojmowaniu planów życiowych oraz społeczno-kulturowych uwarunkowaniach tych planów. W: Jasiński, Z., Lewowicki, T. i Nikitorowicz, J. red. Plany życiowe młodzieży z terenów pograniczy. Opole: Instytut Nauk Pedagogicznych Uniwersytetu Opolskiego, ss. 7-12.

Lewowicki, T. i Jasiński, Z. 1998, Potencjał społeczno-kulturowy regionu jako czynnik determinujący poczucie tożsamości i plany życiowe, W: Jasiński, Z., Lewowicki, T. i Nikitorowicz, J. red. Potencjat spoteczno-kulturowy polskich pograniczy. Opole: Instytut Nauk Pedagogicznych Uniwersytetu Opolskiego.

Łangowska-Marcinowska, K. 2020. Zmiany w życiu codziennym mieszkańców pogranicza polsko-czeskiego i ich aktywność społeczna. W: Jasiński, Z. i Nowak, Z. red. Jakość i styl życia oraz plany życiowe i tożsamość kulturowa mieszkańców polsko-czeskiego pogranicza po przyjęciu Polski i Czech do Unii Europejskiej. Kraków: Wydawnictwo Petrus, ss. 135-151.

Murin, M. 2020. Plany życiowe mieszkańców czesko-polskiego pogranicza. W: Jasiński, Z. i Nowak, Z. red. Jakość i styl życia oraz plany życiowe $i$ tożsamość kulturowa mieszkańców polsko-czeskiego pogranicza po przyjęciu Polski i Czech do Unii Europejskiej. Kraków: Wydawnictwo Petrus, ss. 169-188.

Nalepová, V. 2020. Dynamika i kierunek zmian wskaźników jakości życia w regionie Morawsko-Śląskim po wejściu do UE. W: Jasiński, Z. i Nowak, Z. red. Jakość i styl życia oraz plany życiowe i tożsamość kulturowa mieszkańców polsko-czeskiego pogranicza po przyjęciu Polski i Czech do Unii Europejskiej. Kraków: Wydawnictwo Petrus, ss. 79-104.

Navrátil, B. 2020. Społeczno-kulturalny potencjał czesko-polskiego pogranicza - współpraca transgraniczna i współne euroregiony. W: Jasiński, Z. i Nowak, Z. red. Jakość i styl życia oraz plany życiowe i tożsamość kulturowa mieszkańców polsko-czeskiego pogranicza po przyjęciu Polski i Czech do Unii Europejskiej. Kraków: Wydawnictwo Petrus, ss. 49-61.

Nikitorowicz, J. 2009. Edukacja regionalna i międzykulturowa. Warszawa: WAiP. 
Nowak, Z.M. 2020. Jakość życia i styl życia w czasie wolnym młodych mieszkańców polsko-czeskiego pogranicza. W: Jasiński, Z. i Nowak, Z. red. Jakość i styl życia oraz plany życiowe i tożsamość kulturowa mieszkańców polsko-czeskiego pogranicza po przyjęciu Polski i Czech do Unii Europejskiej. Kraków: Wydawnictwo Petrus, ss. 105-133.

„Nyski Rynek Pracy. Biuletyn Informacyjny Powiatowego Urzędu Pracy w Nysie" 2006, nr 1, wrzesień.

Śliwa, S. 2020. Plany życiowe mieszkańców pogranicza polsko-czeskiego w opinii uczniów i studentów z Polski. W: Jasiński, Z. i Nowak, Z. red. Jakość i styl życia oraz plany życiowe i tożsamość kulturowa mieszkańców polsko-czeskiego pogranicza po przyjęciu Polski i Czech do Unii Europejskiej. Kraków: Wydawnictwo Petrus, ss. 153-167.

\section{Netografia}

euregio pl-cz (euroregions.org). https://nysa.praca.gov.pl/documents/157987/13468394/2020. Analiza o sytuacji na rynku pracy 2020 (21.03.2021).

https://www.bing.com/search?q=powiatowy+urz $\%$ C4\% $85 d+$ pracy+w+prudniku, stopa bezrobocia (21.03.2021).

https://www.infor.pl/wskazniki/glowny-urzad-statystyczny/186,428.Przecietna-stopa-bezrobocia (21.03.2021).

\section{The project "The quality of life, lifestyle, life plans and identity of the inhabitants of the Polish-Czech borderland after entering the European Union by Poland and the Czech Republic"}

Abstract: The article presents a project implemented by partner universities in Poland (Opole) in and the Czech Republic (Havirzów), concerning the quality of life and lifestyle as well as life plans and identity of the inhabitants of the PolishCzech borderland after the accession of Poland and the Czech Republic to the European Union. The objectives of the project, methodological assumptions, and selected research results characterizing four research categories were presented: quality and lifestyle, life plans and identity of the borderland inhabitants from the socio-cultural potential of the borderland, the Poland and the Czech Republic admission to the EU, intercultural education and from the borderland's perspective. Surveys conducted on the Polish side in the Euroregion Pradziad and on the Czech side in the Euroregion Beskidy on a total group of 615 pupils and 502 
students, allowed for a diagnosis of the analyzed problems and for defining the determinants of the analyzed categories.

Keywords: quality of life and lifestyle, socio-cultural potential, borderland, life plans, borderland identity

Translated by Bartłomiej Roczek 